PRODUCTION

ENGINEERING ARCHIVES
2015, Vol. 6, No. 1, pp 14-16

ISSN 2353-5156 (print version)

ISSN 2353-7779 (online version)

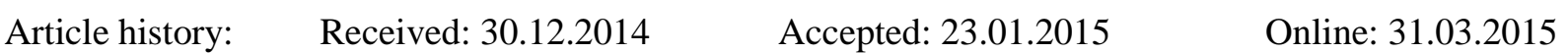

\title{
Evaluation of paving stone production quality
}

\section{Piotr Sygut}

Institute of Production Engineering, Faculty of Management, Częstochowa University of Technology, Armii Krajowej 19B, 42-201 Czestochowa, Poland, e-mail: piotr.sygut.wz@gmail.com

\begin{abstract}
The results of tests carried out for the company involved in the production of paving stones. The study used the Pareto-Lorenz diagram. After analyzing the production process 10 discrepancies were identified. The Pareto-Lorenz diagram shows that the highest value is cumulative deficiency "uneven concrete mix to fill the form on the structural layer and a top." The results indicate that another cause of incompatibilities in terms of the cumulative value is the "poorly chosen concrete mix".
\end{abstract}

Key words - paving stones, Pareto-Lorenz diagram, quality evaluation

\section{Introduction}

Paving stones is a prefabricated building element made from plain concrete designed to build, among others, paving, squares, parking lots, pedestrian routes and halls.

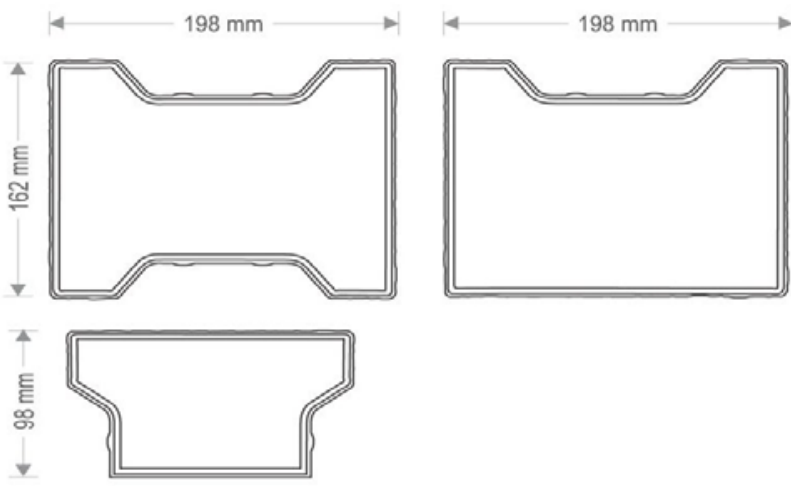

Fig. 1. Paving stones „behaton” type

Source: Advertising materials BRUK company
The main features that make paving stones attractive are a variety of forms and shapes, high durability and the ability to re-build after the demolition. Paving stones according to the production method can be produced from one or two layers of concrete. In the paving stones bilayer, the surface layer should have a minimum thickness of $5 \mathrm{~mm}$ and to be strongly associated with lower layer - construction. In contrast, the paving stones are made of a single layer of one type of concrete. For this reason ,they can be manufactured faster than bilayer. Their disadvantage is the need for the manufacture of concrete mixes with a much higher point of the sand, which in turn causes an increase in the consumption of cement. Furthermore, increased consumption of the dye when it is necessary to dyeing the entire mass of concrete. The basic shape of the cube is a square, rectangle or hexagon. There are also dozens of other forms as well as liaison and halfcubes. The usable area of the paving stones may be modeling (profiling) and tinting. The basic color is grey due to the color of cement. However, you can dye 
the paving stones, allowing to get a lot of colors and shades (BRYLICKI W. 1998, BORKOWSKI S., SYGUT P., RUTKOWSKI W., 2013). The edges of the usable space can be chamfered or beveled. The side walls should have an external cutter (ie. spacer), which is a natural dilation.

For the production of concrete paving, the following materials are applicable::

- high grade Portland cements,

- aggregate fine sand with the grain size 0 - $2 \mathrm{~mm}$,

- fractionated aggregates gravel - pebbles and broken or their mixtures with a grain size of $2-8$ and 2 - $16 \mathrm{~mm}$,

- mineral supplements,

- chemical additives,

- pigments,

- water.

Proper determination of the composition of the concrete - that is its design and preparation and transportation to the forming station - has a decisive impact on the quality of the concrete paving stones. The design of concrete composition with the assumed properties in the hardened state can be reduced to the following basic issues:

- corresponding qualitative selection of the basic ingredients, ie. cement, aggregate and water;

- proper selection of the quantitative component of the grout (cement and water), providing after a predetermined time corresponding properties of the grout in the hardened state, and thus the corresponding properties of the concrete;

- proper selection of the quantitative grout and gravel, permitting to obtain a dense material with minimum costs of its production.

In addition, it is also necessary to define the requirements for concrete. These features must ensure proper implementation of the concrete element, ie:

- allow the transport of concrete for forming station without segregation of the components (due to their different densities),

- allow its density, which is the closest possible arrangement of the grains of cement and aggregate, combined with the closest possible removal of air.

In summary, the design of concrete composition is to the qualitative and quantitative selection of ingredients to mix both concrete and hardened concrete properties have started. With respect to the concrete mix in terms of its basic properties such as consistency and workability. Fig. 1 shows the cobblestones with dimensions of "behaton" type.

\section{Evaluation of the tested product qual- ity}

The study used analysis of Pareto-Lorenz described in the works BORKOWSKI S., SELEJDAK J., SALAMON SZ. 2006, BORKOWSKI S. 2004, BORKOWSKI S., ULEWICZ R 2009. The analyzed company was carried out with an incompatibility occurring in the production of paving stones. In table 1 causes of incompatibility that occur during the production of paving stones are ranked.

Table 1. Causes of incompatibility in the production of paving stones

\begin{tabular}{|c|c|c|c|c|}
\hline $\begin{array}{c}\text { Sym } \\
\text { bol }\end{array}$ & $\begin{array}{c}\text { Name } \\
\text { incompa- } \\
\text { tibility }\end{array}$ & $\begin{array}{l}\text { The } \\
\text { frequ- } \\
\text { ency of } \\
\text { occur- } \\
\text { rence }\end{array}$ & $\begin{array}{c}\text { The per- } \\
\text { centage of } \\
\text { incompa- } \\
\text { tibility } \\
\text { [\%] }\end{array}$ & $\begin{array}{l}\text { The cu- } \\
\text { mulative } \\
\text { share of } \\
\text { incompat- } \\
\text { ibility [\%] }\end{array}$ \\
\hline N1 & $\begin{array}{c}\text { Uneven } \\
\text { filling to } \\
\text { form a } \\
\text { layer of } \\
\text { concrete } \\
\text { mixture } \\
\text { design and } \\
\text { top }\end{array}$ & 24 & 19.51 & 19.51 \\
\hline N2 & $\begin{array}{c}\text { Improper- } \\
\text { ly selected } \\
\text { concrete } \\
\text { mixture }\end{array}$ & 22 & 17.88 & 37.39 \\
\hline N3 & $\begin{array}{c}\text { Improper- } \\
\text { ly sized } \\
\text { vibrating } \\
\text { time of } \\
\text { initial and } \\
\text { main }\end{array}$ & 15 & 12.19 & 49.58 \\
\hline N4 & $\begin{array}{c}\text { Lack of } \\
\text { employee }\end{array}$ & 14 & 11.38 & 60.69 \\
\hline
\end{tabular}




\begin{tabular}{|c|c|c|c|c|}
\hline & $\begin{array}{l}\text { engage- } \\
\text { ment in } \\
\text { the work } \\
\text { done }\end{array}$ & & & \\
\hline N5 & $\begin{array}{c}\text { Improper } \\
\text { mainte- } \\
\text { nance of } \\
\text { machinery }\end{array}$ & 12 & 9.75 & 70.71 \\
\hline N6 & $\begin{array}{c}\text { The inac- } \\
\text { curacy }\end{array}$ & 11 & 8.94 & 79.65 \\
\hline N7 & $\begin{array}{c}\text { Low- } \\
\text { quality } \\
\text { materials }\end{array}$ & 10 & 8.13 & 87.78 \\
\hline N8 & $\begin{array}{l}\text { Outdated } \\
\text { equipment }\end{array}$ & 6 & 4.87 & 92.65 \\
\hline N9 & $\begin{array}{l}\text { Equ- } \\
\text { ipment } \\
\text { failure }\end{array}$ & 5 & 4.1 & 96.75 \\
\hline N10 & $\begin{array}{l}\text { Poor work } \\
\text { organiza- } \\
\text { tion }\end{array}$ & 4 & 3.25 & 100.0 \\
\hline
\end{tabular}

Source: own interpretation

Based on the data contained in table 1 ParetoLorenz diagram was prepared (Fig. 2).

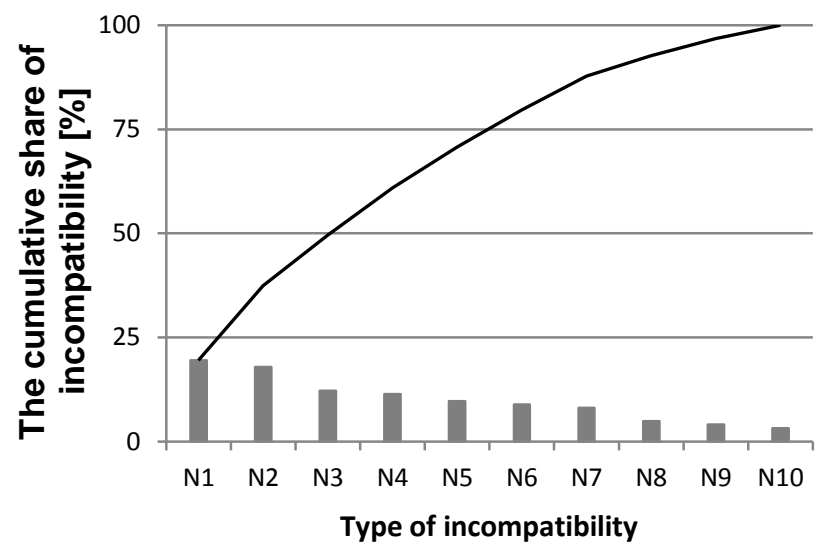

Fig. 2. Diagram Pareto-Lorenz causes of incompatibility occurring in the production of paving stones.
When analyzing the data shown in Fig. 2 it can be stated that: $37.39 \%$ of the causes of incompatibility are responsible for two reasons, namely uneven concrete mixture to fill the form on the top layer and the structural and concrete mixture improperly adjusted. These two reasons account for $20 \%$ of incompatibility. The other 8 kinds of incompatibility are $62.61 \%$ of all the causes that generate the cause during the manufacturing process.

\section{Summary and conclusions}

The subject of the study was concrete paving stones produced by vibro pressing. During the control four basic qualities were subjected to group: aesthetic qualities of the product, the product geometrical characteristics, mechanical properties and durability of the product in the wild. After analyzing the production process 10 incompatibilities were identified. The structure of incompatibilities determined based on the Pareto-Lorenz diagram shows that the highest value is cumulative deficiency "uneven concrete mix to fill the form on the structural layer and a top." The results indicate that another cause of incompatibilities in terms of the cumulative value is that the "poorly chosen concrete mix".

\section{References}

1. BORKOWSKI S., SELEJDAK J., SALAMON Sz. 2006 „Efektywność eksploatacji maszyn i urządzeń”, Wydaw. Wydziału Zarządzania Politechniki Częstochowskiej, Częstochowa.

2. BORKOWSKI S. 2004 „Mierzenie poziomu jakości”, Sosnowiec: Wydaw. Wyższej Szkoły Zarządzania i Marketingu.

3. BORKOWSKI S., UlEWICZ R 2009. „Zarządzanie produkcją. Systemy produkcyjne", Wydawnictwo Oficyna Wydawnicza Humanitas, Sosnowiec.

4. BRYLICKI W., 1998. Kostka brukowa z betonu wibroprasowanego. Wyd. Polski Cement Sp. z o.o, Kraków.

5. BorkowSKi S., SyguT P., RUTKOWSKI W., 2013. Cement Production Process Improvement in Ball Mills. Chapter 12. W: Estimation and Operating Improvement. Monography. Editing and Scientific Elaboration Stanisław Borkowski, Marek Krynke. s.143-151. ISBN 978-9616562-67-6. 